\title{
Phytochemical Analysis of Wild Meethi Neem [Murraya koenigii (L.) Spreng] Collections of Himachal Pradesh
}

\author{
Reetu*, Nageswer Singh, Nilamani Dikshit and Maharishi Tomar
}

ICAR-Indian Grassland and Fodder Research Institute, Jhansi-284003, (UP), India

*Corresponding author

\section{A B S T R A C T}

\section{Keywords}

Ascorbic acid, Flowering stage, Chlorophyll,

Carotenoid content, Anti-oxidant

Article Info

Accepted:

04 November 2019

Available Online:

10 December 2019
Murraya koenigii (L.) Spreng commonly known as 'Curry patta' or 'Meethi Neem' is a native plant of India. The leaves are widely used for flavoring food items for the Indian preparations like curries, chutneys, sambhar, buttermilk, and preparations of egg, fish and meat. Fresh leaves of Meethi Neem contain carotene, nicotinic acid, vitamin $\mathrm{C}$, alkaloids, flavonoids, tannins, volatile oil and also have reported to possess anti-oxidant, antibacterial, antifungal, anti-carcinogenic, hypoglycemic and antihypertensive activity. Fifteen wild Meethi Neem leaf samples collected at three stages viz. pre-flowering, flowering and fruiting stages from 15diverse locations of Kangra and Mandi district of Himachal Pradesh were analyzed to evaluate phytochemical constituents i.e. total chlorophyll, carotenoid content $(\mu \mathrm{g} / \mathrm{g})$ and ascorbic content. The range of variation for phytochemical constituents at three stages varied significantly viz. total chlorophyll ( 0.79 to $1.43,1.31$ to 1.94 and 0.88 to 1.10 $\mathrm{mg} / \mathrm{g}$ ), total carotenoids ( 30.55 to $49.25,49.09$ to 60.81 and 31.24 to $41.42 \mu \mathrm{g} / \mathrm{g}$ ), ascorbic acid (7.01 to $9.82,3.58$ to 6.06 and 2.99 to $4.93 \mathrm{mg} / 100 \mathrm{~g}$ ), respectively. Among all picking stages highest value of total chlorophyll and carotenoid content was observed at flowering stage whereas ascorbic acid content showed highest value at pre-flowering stage.

\section{Introduction}

Mountains support an estimated one-third of terrestrial species diversity (Körner, 2004) and host half of all 34 global biodiversity hotspots (Chape et al., 2008). The Himalayan mountains is well known as a source of medicinal and aromatic plants, which contain variety of bioactive agents. Since the beginning of human civilization, medicinal plants have been used by mankind for its therapeutic value. Medicinal plants are generally tree, shrub, herb, annuals, biennial, tubers, rhizomes and climbers containing bioactive compounds. Some of the medicinal plant includes tulsi, neem, babul, lavender, brahmi, curry patta (Meethi Neem), datura, satavar, arjun and sarpagandhha. Meethi Neem (Murrayakoenigii) is one among them which has been extensively used for culinary 
preparations in Indian kitchen. Murrayakoenigii (L.) Sprengis a native plant of India commonly known as 'Curry patta' or 'Meethi Neem' in Indian dialects, and belongs to the family Rutaceae. It is a shrub or a small tree found throughout India up to an altitude of 1,500m (Ajay et al., 2007).

The plant occurs both in wild and cultivated forms. Wild forms in India are found growing in the hills of Assam, Central India, Himachal Pradesh, Kerala, Punjab, Sikkim, Tamil Nadu, Uttarakhand, West Bengal and Western Ghats (Dastur, 1970). In Southern parts of India, it is cultivated for its aromatic leaves for dish preparations. Flowering starts from the middle of April and ends in the middle of May.

The fruiting continues from the middle of July to the end of August. Meethi neem is extensively known for its medicinal uses, especially aromatic characteristics of leaves and contains carotene, nicotinic acid, vitamin $\mathrm{C}$, vitamin A, calcium, oxalic acid, glycosides alkaloids, flavonoids, tannins, volatile oil and also have reported to possess anti-oxidant, antibacterial, antifungal, anti-carcinogenic, hypoglycemic and antihypertensive activity (Narasimhan et al., 1975).

Curry leaves are also used in the treatment of various diseases like diabetes mellitus, body pain, inflammation, kidney pain, blood disorders and piles. The leaves are widely used for flavouring food items like buttermilk, egg and meat and for the Indian preparations like curries, chutneys and sambhar. There are several evidences about the use of these medicinal plants and their derived products in traditional Chinese, Ayurveda, Siddha, Unani and Tibetan medicines. Ancient literature such as Rigveda, Yajurveda, Atharvaveda, Charak Samhita and Sushrut Samhita also describes their use for the treatment of various health problems (Sekar et al., 2011). Human being uses numerous plants and plant derived products to cure and get relief from various physical and mental illnesses (Balunas and Kinghorn, 2005). The natural compounds in medicinal plants act in a synergistic manner within the human body and provide unique therapeutic properties with minimal or no side-effects. Phytochemical properties of Meethi Neem leaves belonging to higher altitudinalranges of Kangra and Mandi districts of Himachal Pradesh have not been studiedearlier. Hence, the present attempt was made to identify the promising genotype for active photochemical constituents of Meethi Neem available in two high altitude districts of Himachal Pradesh.

\section{Materials and Methods}

\section{Sampling}

The research material for the present study comprised of 15 wild Meethi Neem leaves samples which were collected during 2013-14 at three different stages i.e. before flowering, at the time of flowering and at fruiting stage (Fig. 1). Approx. $500 \mathrm{gm}$ fresh leaves were collected from 15 randomly selected plants from 15 different locations of Kangra and Mandi Districts of Himachal Pradesh (Table $1)$.

\section{Extraction and estimation of total chlorophyll and carotenoids}

Total chlorophyll and total carotenoids in fresh Meethi Neem leaves were estimated by the methods of Jayraman (1981) followed by Davies (1976). $0.2 \mathrm{~g}$ fresh leaves were ground in pestle and mortar with the addition of $5 \mathrm{ml}$ of 80 per cent acetone. This paste was centrifuged for $15 \mathrm{~min}$ at 4,000 $\mathrm{rpm}$. The supernatant was transferred to a $50 \mathrm{ml}$ beaker.

The chlorophylls and carotenoids were repeatedly extracted out with $20 \mathrm{ml}(5-5 \mathrm{ml}$ repeatedly, 4 times) 80 per cent acetone until 
residues became colourless. Finally, the volume was made up to $20 \mathrm{ml}$ with 80 per cent acetone and absorbance of the extracted solution was measured at $663 \mathrm{~nm}, 645 \mathrm{~nm}$ and $480 \mathrm{~nm}$ on spectrophotometer Model Merck SpectroquantPharo 100.

The extent of chlorophylls (mg/ g) was calculated by the following equation:

Total chlorophylls $=[20.2($ A 645) $+8.02(\mathrm{~A}$ 663)] x V/(1000xW)

The amount of total carotenoids $(\mu \mathrm{g} / \mathrm{g})$ was calculated with following equation:

Total carotenoids $=[\mathrm{A} 480+0.114(\mathrm{~A}$ 663 $)-$ 0.638 (A 645) x V/W

Where, $A=$ absorbance at specific wavelengths, $\mathrm{V}=$ final volume extract, $\mathrm{W}=$ fresh weight of tissue

\section{Extraction and estimation of Ascorbic} acid

Ascorbic acid content in Meethi Neem leaves was analyzed by the method of AOAC, 1990.Twenty-five gram of fresh Meethi Neem leaves ground with $25 \mathrm{ml}$ of 2.0 per cent oxalic acid in pestle and mortar to get slurry.

The total weight of slurry was recorded. 10 $\mathrm{g}$ of this slurry was taken in a beaker and volume was made up to $25 \mathrm{ml}$ with 1 per cent oxalic acid. The content of the beaker was filtered through Whatman No.1 filter paper. $5.0 \mathrm{ml}$ of this filtrate was pipette out and titrated against a dye solution (2, 6 dichlorophenol indophenol). Three concordant readings were recorded. Lascorbic acid was used as a standard titrated against dye. The amount of ascorbic acid (mg /100 g) was calculated using following formula:
Ascorbic acid (mg/100g)

Standard conc. of ascorbic acid

$\mathrm{x}$ A $\mathrm{x}$ Volume made up $\mathrm{x} \mathrm{B}$

=------------------------------ x 100

Titer value of Standard $\mathrm{x}$

Wt. of slurry used $x \mathrm{~S}$

$\mathrm{x}$ Vol. used for titration

Where $\mathrm{A}=$ Titer value of sample, $\mathrm{B}=$ Total weight of slurry, $S=$ Weight of sample $(\mathrm{g})$

\section{Statistical analysis}

All phytochemical analysis was carried out in triplicate to reduce the experimental error to a minimum. Statistical analyses were performed using Statistical Analysis Software, Version 9.2 (SAS, 2009). Duncan's Multiple Range Test (DMRT) is used for variation analysis.

\section{Results and Discussion}

The Meethi Neem collections were collected from $31^{\circ} 47^{\prime}-32^{\circ} 50^{\prime} \mathrm{N}$ and $76^{\circ} 25^{\prime}-76^{\circ} 56^{\prime} \mathrm{E}$ and $689-1339$ meter altitudinal range of Kangra and Mandi Districts of Himachal Pradesh. The results revealed that there were significant differences among the 15 Meethi Neem collectionswith respect total chlorophyll, carotenoids and ascorbic acid content. Variation in chlorophyll, carotenoids and ascorbic acid content of Meethi Neem collections at different picking stages viz. preflowering, flowering and fruiting stage are mentioned (Table 2).

\section{Total chlorophyll content}

Data in respect of total chlorophyll content of Meethi Neem collections at different stages are depicted in Table 2. A significant variation was observed in total chlorophyll content. The value ranged from 0.79 to $1.43,1.31$ to 1.94 and 0.88 to $1.10 \mathrm{mg} / \mathrm{g}$ at pre-flowering, flowering and fruiting stage, respectively. At pre-flowering stage, the highest value for total 
chlorophyll content was observed in Dhramn $(1.43 \mathrm{mg} / \mathrm{g})$ followed by Tang (1.38) and Sagned $(1.37 \mathrm{mg} / \mathrm{g})$ whereas its lowest value was noticed in Madi $(0.79 \mathrm{mg} / \mathrm{g})$.Subsequently at flowering stage, Mlan $(1.94 \mathrm{mg} / \mathrm{g})$ showed maximum value of total chlorophyll content followed by Kunnu (1.93 $\mathrm{mg} / \mathrm{g})$ and Dharampur $(1.87 \mathrm{mg} / \mathrm{g})$ whereas lowest value was found in Pudva $(1.31 \mathrm{mg} / \mathrm{g})$. At fruiting stage, Dhira $(1.10 \mathrm{mg} / \mathrm{g})$ showed highest value of total chlorophyll content followed by Sagned $(1.06 \mathrm{mg} / \mathrm{g})$ and Kunnu $(1.05 \mathrm{mg} / \mathrm{g})$.
Kotropi $(0.88 \mathrm{mg} / \mathrm{g})$ had lowest value of total chlorophyll content at fruiting stage. In general, leaf chlorophyll content increased during flowering stage and thereafter decreased more rapidly during the fruiting stage. The decrease in chlorophyll content might be due to translocation of metabolites from leaves to growing grain. Garg et al., (2012) reported the total chlorophyll content of Meethi Neem was $0.026 \mathrm{~g} / \mathrm{L}$ i.e. $2.6 \mathrm{mg} / \mathrm{g}$ which was nearly close to the present value of total chlorophyll content.

Table.1 Sampling details of 15 different wild Meethi Neem collections

\begin{tabular}{|c|c|c|c|c|}
\hline Sr. No. & $\begin{array}{l}\text { Collections } \\
\text { Name }\end{array}$ & Tehsil, District & $\begin{array}{l}\text { Altitude range } \\
\text { (msl) }\end{array}$ & Latitude/longitude \\
\hline & \multicolumn{4}{|c|}{ Kangra } \\
\hline 1 & Pudva & Palampur, Kangra & $709 \mathrm{~m}$ & $31^{0} 57^{\prime} \mathrm{N} / 76^{0} 26^{\prime} \mathrm{E}$ \\
\hline 2 & Dhramn & Jaisinghpur, Kangra & $807 \mathrm{~m}$ & $31^{0} 59^{\prime} \mathrm{N} / 76^{0} 32^{\prime} \mathrm{E}$ \\
\hline 3 & Dhira & Dhira, Kangra & $946 \mathrm{~m}$ & $32^{0} 01^{\prime} \mathrm{N} / 76^{0} 27^{\prime} \mathrm{E}$ \\
\hline 4 & Mlan & NB, Kangra & $960 \mathrm{~m}$ & $32^{0} 07^{\prime} \mathrm{N} / 76^{0} 25^{\prime} \mathrm{E}$ \\
\hline 5 & Malghota & Baijnath, Kangra & $1047 \mathrm{~m}$ & $32^{0} 03^{\prime} \mathrm{N} / 76^{0} 38^{\prime} \mathrm{E}$ \\
\hline \multirow[t]{2}{*}{6} & Tang & Dharamshala, Kangra & $1069 \mathrm{~m}$ & $32^{0} 09^{\prime} \mathrm{N} / 76^{0} 25^{\prime} \mathrm{E}$ \\
\hline & \multicolumn{4}{|c|}{ Mandi } \\
\hline 7 & Nagri & Palampur, Kangra & $1278 \mathrm{~m}$ & $32^{0} 07^{\prime} \mathrm{N} / 76^{0} 28^{\prime} \mathrm{E}$ \\
\hline 8 & Sagned & Sarkaghat, Mandi & $689 \mathrm{~m}$ & $31^{0} 48^{\prime} \mathrm{N} / 76^{0} 45^{\prime} \mathrm{E}$ \\
\hline 9 & Dharampur & Dharampur, Mandi & $751 \mathrm{~m}$ & $31^{0} 47^{\prime} \mathrm{N} / 76^{0} 44^{\prime} \mathrm{E}$ \\
\hline 10 & Lad Badhol & Lad Badhol, Mandi & $777 \mathrm{~m}$ & $31^{0} 55^{\prime} \mathrm{N} / 76^{0} 42^{\prime} \mathrm{E}$ \\
\hline 11 & Neri & Jogindernagar, Mandi & $827 \mathrm{~m}$ & $31^{0} 49^{\prime} \mathrm{N} / 76^{0} 46^{\prime} \mathrm{E}$ \\
\hline 12 & Madi & Sandhol, Mandi & $1016 \mathrm{~m}$ & $31^{0} 48^{\prime} \mathrm{N} / 76^{0} 44^{\prime} \mathrm{E}$ \\
\hline 13 & Drang & Mandi, Mandi & $1121 \mathrm{~m}$ & $31^{0} 49^{\prime} \mathrm{N} / 76^{0} 56^{\prime} \mathrm{E}$ \\
\hline 14 & Kunnu & Padar, Mandi & $1201 \mathrm{~m}$ & $32^{0} 50^{\prime} \mathrm{N} / 76^{0} 55^{\prime} \mathrm{E}$ \\
\hline 15 & Kotropi & Padar, Mandi & $1339 \mathrm{~m}$ & $31^{0} 54^{\prime} \mathrm{N} / 76^{0} 53^{\prime} \mathrm{E}$ \\
\hline
\end{tabular}


Table.2 Variation in total chlorophyll, carotenoids and ascorbic acid content of Meethi Neem collections at different picking stages

\begin{tabular}{|c|c|c|c|c|c|c|c|c|c|c|}
\hline \multirow[t]{2}{*}{ Sr No. } & \multirow{2}{*}{$\begin{array}{c}\text { Collection } \\
\text { Name }\end{array}$} & \multicolumn{3}{|c|}{ Total chlorophyll Content(mg/g) } & \multicolumn{3}{|c|}{ Total carotenoids content $(\boldsymbol{\mu g} / \mathrm{g})$} & \multicolumn{3}{|c|}{ Ascorbic content (mg/100g) } \\
\hline & & $\begin{array}{c}\text { Pre- } \\
\text { Flowering }\end{array}$ & Flowering & Fruiting & $\begin{array}{c}\text { Pre- } \\
\text { Flowering }\end{array}$ & Flowering & Fruiting & $\begin{array}{c}\text { Pre- } \\
\text { Flowering }\end{array}$ & Flowering & Fruiting \\
\hline 1 & Pudva & $1.11^{\mathrm{f}}$ & $1.31^{\mathrm{a}}$ & $0.99^{\mathrm{e}}$ & $44.84^{\mathrm{i}}$ & $53.17^{\mathrm{d}}$ & $32.31^{b}$ & $8.49^{\mathrm{h}}$ & $5.89^{n}$ & $4.20^{\mathrm{h}}$ \\
\hline 2 & Dhramn & $1.43^{\mathrm{m}}$ & $1.76^{\mathrm{g}}$ & $1.03^{h}$ & $48.73^{\mathrm{n}}$ & $58.78^{j}$ & $38.95^{\mathrm{g}}$ & $8.60^{\mathrm{i}}$ & $4.62^{\mathrm{e}}$ & $4.93^{\mathrm{m}}$ \\
\hline 3 & Dhira & $1.24^{\mathrm{i}}$ & $1.83^{j}$ & $1.10^{\mathrm{k}}$ & $45.27^{\mathrm{k}}$ & $57.69^{h}$ & $33.06^{\mathrm{d}}$ & $8.21^{\mathrm{f}}$ & $4.39^{c}$ & $3.53^{\mathrm{e}}$ \\
\hline 4 & Mlan & $1.06^{\mathrm{e}}$ & $1.94^{\circ}$ & $0.99^{\mathrm{d}}$ & $43.12^{\mathrm{h}}$ & $59.79^{1}$ & $35.48^{\mathrm{f}}$ & $8.87^{j}$ & $4.59^{\mathrm{d}}$ & $3.58^{\mathrm{f}}$ \\
\hline 5 & Malghota & $0.83^{b}$ & $1.50^{\mathrm{d}}$ & $1.00^{\mathrm{et}}$ & $40.21^{\mathrm{d}}$ & $52.13^{c}$ & $32.81^{\mathrm{c}}$ & $9.72^{n}$ & $5.02^{h}$ & $3.23^{c}$ \\
\hline 6 & Tang & $1.38^{1}$ & $1.84^{\mathrm{k}}$ & $1.03^{h}$ & $47.46^{\mathrm{m}}$ & $57.18^{\mathrm{g}}$ & $35.66^{\mathrm{f}}$ & $9.82^{\circ}$ & $4.89^{g}$ & $3.11^{b}$ \\
\hline 7 & Nagri & $1.26^{j}$ & $1.86^{1}$ & $0.98^{d}$ & $42.21^{\mathrm{g}}$ & $59.11^{\mathrm{k}}$ & $40.21^{i}$ & $9.66^{\mathrm{m}}$ & $5.05^{i}$ & $4.89^{1}$ \\
\hline 8 & Sagned & $1.37^{1}$ & $1.43^{b}$ & $1.06^{\mathrm{j}}$ & $49.25^{\circ}$ & $49.09^{a}$ & $34.49^{e}$ & $9.11^{\mathrm{k}}$ & $5.35^{\mathrm{k}}$ & $2.99^{\mathrm{a}}$ \\
\hline 9 & Dharampur & $1.27^{\mathrm{k}}$ & $1.87^{\mathrm{m}}$ & $0.96^{\mathrm{b}}$ & $41.23^{\mathrm{f}}$ & $60.44^{\mathrm{m}}$ & $41.27^{j}$ & $7.64^{d}$ & $3.58^{\mathrm{a}}$ & $3.56^{\mathrm{ef}}$ \\
\hline 10 & Lad Badhol & $1.23^{\mathrm{h}}$ & $1.83^{1}$ & $1.02^{\mathrm{g}}$ & $46.87^{1}$ & $58.03 \mathrm{i}$ & $39.64^{\mathrm{h}}$ & $7.01^{\mathrm{a}}$ & $4.21^{b}$ & $3.26^{d}$ \\
\hline 11 & Neri & $1.17^{\mathrm{g}}$ & $1.53^{\mathrm{e}}$ & $1.03^{h}$ & $40.48^{\mathrm{e}}$ & $52.15^{\mathrm{c}}$ & $33.18^{d}$ & $7.18^{c}$ & $4.81^{\mathrm{f}}$ & $3.83^{\mathrm{g}}$ \\
\hline 12 & Madi & $0.79^{\mathrm{a}}$ & $1.82^{\mathrm{h}}$ & $1.01^{\mathrm{f}}$ & $30.55^{\mathrm{a}}$ & $55.51^{\mathrm{f}}$ & $31.24^{\mathrm{a}}$ & $9.47^{1}$ & $5.67^{\mathrm{m}}$ & $4.82^{j}$ \\
\hline 13 & Drang & $0.93^{c}$ & $1.49^{c}$ & $0.97^{\mathrm{c}}$ & $38.19^{c}$ & $49.28^{b}$ & $31.34^{\mathrm{a}}$ & $7.95^{\mathrm{e}}$ & $6.06^{\circ}$ & $4.60^{i}$ \\
\hline 14 & Kunnu & $0.83^{b}$ & $1.93^{\mathrm{n}}$ & $1.05^{\mathrm{i}}$ & $35.19^{b}$ & $60.81^{\mathrm{n}}$ & $41.42^{j}$ & $7.18^{b}$ & $5.49^{1}$ & $3.56^{\mathrm{f}}$ \\
\hline 15 & Kotropi & $1.03^{\mathrm{d}}$ & $1.60^{f}$ & $0.88^{\mathrm{a}}$ & $45.08^{j}$ & $54.64^{\mathrm{e}}$ & $35.55^{\mathrm{f}}$ & $8.36^{\mathrm{g}}$ & $5.14^{j}$ & $4.85^{\mathrm{k}}$ \\
\hline Mean & & 1.13 & 1.70 & 1.01 & 42.58 & 55.85 & 35.78 & 8.49 & 4.98 & 3.93 \\
\hline Range & & $0.79-1.43$ & $1.31-1.94$ & $0.88-1.10$ & $30.55-49.25$ & $49.09-60.81$ & $31.24-41.42$ & $7.01-9.82$ & $3.58-6.06$ & $2.99-4.93$ \\
\hline
\end{tabular}

*Figures having same superscripts are non-significant at $95 \%$ confidence level 
Fig.1 Plants of Murraya koenigii (L.) Spreng showing three different stages

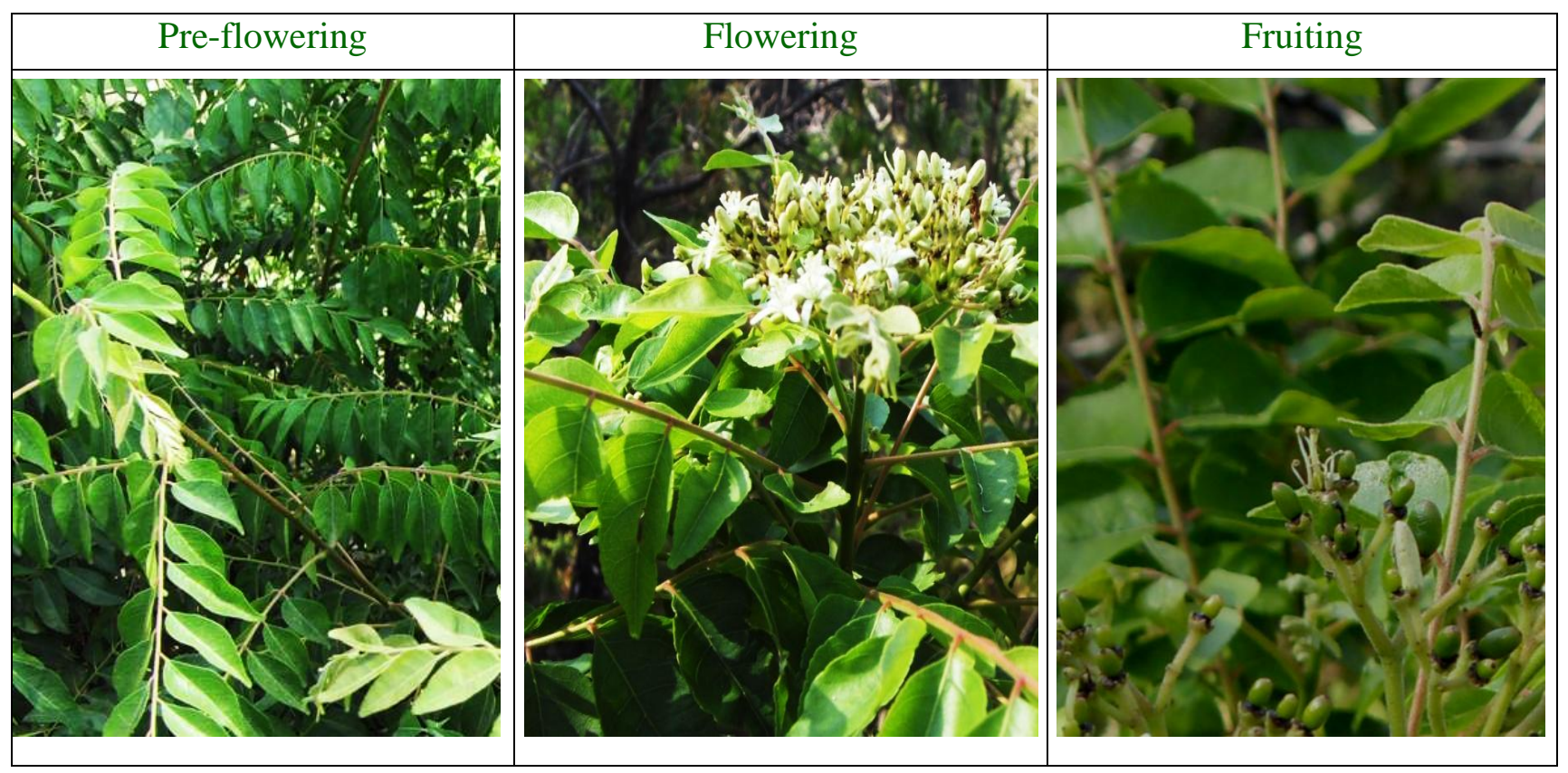

\section{Total carotenoid content}

Variability in total carotenoids content was evaluated (Table 2). It is evident from the data that at pre-flowering, flowering and fruiting stages the total carotenoids significantly varied from 30.55 to $49.25,49.09$ to 60.81 and 31.24 to $41.42(\mu \mathrm{g} / \mathrm{g})$, respectively. At preflowering stage, highest value for this parameter was noticed in Sagned $(49.25 \mu \mathrm{g} / \mathrm{g})$ followed by Dhramn $(48.73 \mu \mathrm{g} / \mathrm{g})$ and Tang (47.46 $\mu \mathrm{g} / \mathrm{g}$ ). The other collections showed significantly lower value of carotenoids content with minimum value exhibited by Madi $(30.55 \mu \mathrm{g} / \mathrm{g})$. At flowering stage, Kunnu (60.81 $\mu \mathrm{g} / \mathrm{g})$, Dharampur (60.44 $\mu \mathrm{g} / \mathrm{g})$ followed by Mlan $(59.787 \mu \mathrm{g} / \mathrm{g})$ showed the highest value of total carotenoids content. The lowest value was recorded in Madi $(49.09 \mu \mathrm{g} / \mathrm{g})$.At fruiting stage, Kunnu (41.42 $\mu \mathrm{g} / \mathrm{g})$, Dharampur $(41.27 \mu \mathrm{g} / \mathrm{g}$ ) followed by Nagri $(40.21 \mu \mathrm{g} / \mathrm{g})$ were recorded to have the highest total carotenoids content. Madi (31.24 $\mu \mathrm{g} / \mathrm{g}$ ) showed lowest value for this parameter. Among all collections, Sagned and Kunnu showed highest value of total carotenoid content. Singh et al., (2014) reported carotene content in curry leaves as $7560 \mu \mathrm{g} / \mathrm{g}(75.60$ $\mu \mathrm{g} / \mathrm{g}$ ) in fresh leaves which is nearly close to the present findings.

\section{Ascorbic acid content}

The variability in ascorbic acid content at different stages in Meethi Neem samples was analyzed and depicted (Table 2). Ascorbic acid content showed a variation ranging from 7.01 to $9.82,3.58$ to 6.06 and 2.99 to 4.93 $(\mathrm{mg} / 100 \mathrm{~g})$ at pre-flowering, flowering and fruiting stage, respectively. At pre-flowering stage Tang $(9.82 \mathrm{mg} / 100 \mathrm{~g})$ followed by Malghota $(9.72 \mathrm{mg} / 100 \mathrm{~g})$ and Nagri (9.66 $\mathrm{mg} / 100 \mathrm{~g}$ ) exhibited higher ascorbic acid content as compared to other collections.

Singh et al., (2014) reported the vitamin C content of Meethi Neem as $4 \mathrm{mg} / 100 \mathrm{~g}$. The minimum value of ascorbic acid was showed by Lad Badhol $(7.013 \mathrm{mg} / 100 \mathrm{~g})$.At flowering stage Drang (6.06 mg/100g), Pudva (5.89 $\mathrm{mg} / 100 \mathrm{~g}$ ) accompanied by Madi (5.67 $\mathrm{mg} / 100 \mathrm{~g}$ ) showed maximum ascorbic acid 
content. The minimum value at flowering stage was exhibited by Dharampur (3.58 $\mathrm{mg} / 100 \mathrm{~g})$. At fruiting stage, Dharamn (4.93 $\mathrm{mg} / 100 \mathrm{~g})$, followed by Nagri $(4.89 \mathrm{mg} / 100 \mathrm{~g})$ and Kotropi $(4.85 \mathrm{mg} / 100 \mathrm{~g})$ were observed to possess highest ascorbic acid content. The lowest value was recorded in Sagned (2.99 $\mathrm{mg} / 100 \mathrm{~g}$ ). Based on the three picking stages Tang, Drang and Dhramn exhibited highest value of ascorbic acid content. Singh et al., (2014) reported the vitamin C content of Meethi Neem as $4 \mathrm{mg} / 100 \mathrm{~g}$. A higher level of ascorbic acid in the developing leaves could be due to the fact that ascorbic acid is essential at the early growth stages.

Plants at this stage are metabolically more active as they require higher concentrations of essential compounds for growth. The lower values in mature plants might be due to oxidative stress in plant at mature stage (Uddin et al., 2012).

Besides its use as flavoring food items, curry leaves are considered as medicinal and reported to possess active principle for several diseases like diabetes mellitus, body pain, inflammation, kidney pain, blood disorders and piles in human beings. Based on the three picking stages viz. pre flowering, flowering and fruiting stages Mlan, Kunnu and Tang collections exhibited highest value of total chlorophyll, carotenoids and ascorbic acid content. Phytochemical composition and diversity in wild populations of curry leaves is enormous. Information on chemodemes of Murraya koenigii (L.) Spreng from higher altitudes of Terai and northern Himalayan ranges will be rewarding. Hence, a comprehensive programme on acquisition of the material from mountainous hilly ranges of Himalaya will not only help to save the species from extinction but also in identification of phytochemically superior lines for conservation and future research programmes.

\section{References}

Ajay, S., Rahul, S., Sujit, G., Paras, M., Mishra, A., and Gaurav, A. 2007. Comprehensive review: Murraya koenigii Linn. Asian Journal of Pharmacy and Life Sciences 1(4): 417425.

A.O.A.C. 1990. Official Methods of Analysis of the Association of Official Analytical Chemists. 11th ed. Washington, D.C.

Balunas, M.J., and Kinghorn, A.D. 2005. Drug discovery from medicinal plants. Life Sciences 78: 431 - 441.

Chape, S., Spalding, M.D., Jenkins, M.D. 2008. The world's protected areas. UNEP-World Conservation Monitoring Centre, Cambridge.

Dastur, J.F. 1970. Medicinal plants of India and Pakistan, third edition. P. 115.

Davies, B.H. 1976. Carotenoids. In chemistry and biochemistry of plant pigments, Vol. 2 (Goodwin T.W., editor) Academic Press, London, New York, San Francisco. pp $38-165$.

Garg, D., Muley, A., Khare, N., and Marar, T. 2012. Comparative analysis of phytochemical profile and antioxidant activity of some Indian culinary herbs. Research Journal of Pharmaceutical, Biological and Chemical Sciences 3 (3): 845-854.

Jayraman, J. 1981. In: Laboratory manual in biochemistry. Willay Eastern Pvt. Ltd., New Delhi, India. Pp 122-123.

Körner, C. 2004. Mountain biodiversity, its causes and function. Ambio, Special Report 13:11-17. doi: 10.1111/j.13652699.2003.01043.x.

Narasimhan, N.S., Paradkar, M.V., Chitguppi, V.P., and Kelkar, S.L. 1975. Alkaloids of Murrayakoenigii: Structures of mahanimbine, koenimbine, mahanine, koenine, koenigine, koenidine \& isomahanimbine. Indian Journal of 
Chemistry 13: 993-999.

SAS. 2009. Statistical Analysis Software System, Version 9.2. SAS Institute, Cary, NC, USA.

Sekar, D.K., Kumar, G., Karthik, L., and Rao, K.V.B. 2011. A review on pharmacological and phytochemical properties of Aegle marmelos (L.) Corr. Serr. (Rutaceae). Asian Journal of Plant Science and Research 1(2): 817.

Singh, S., Omreb, P.K. and Mohan, S.M.
2014. Curry Leaves (Murraya koenigii Linn. Sprengal) A Mircale Plant. Indian Journal of Scientific Research 4 (1): 46-52.

Uddin, M.D, Juraimi, A.S.S., Ali, M.E., and Ismail, M.E. 2012. Evaluation of antioxidant properties and mineral composition of purslane (Portulaca oleracea L.) at different growth stages. International Journal of Molecular Sciences13: 10257-10267.

\section{How to cite this article:}

Reetu, Nageswer Singh, Nilamani Dikshit and Maharishi Tomar. 2019. Phytochemical Analysis of Wild Meethi Neem [Murraya koenigii (L.) Spreng] Collections of Himachal Pradesh. Int.J.Curr.Microbiol.App.Sci. 8(12): 89-96.

doi: https://doi.org/10.20546/ijcmas.2019.812.014 